\title{
The Mediation Role of Organizational Commitment in the Relationship between Strategic Human Resources Management and Individual Performance
}

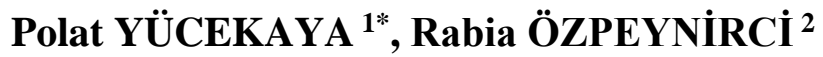 \\ ${ }^{1}$ Çanakkale Onsekiz Mart Üniversity, Turkey (Yazıcızade District, Öğretmen Refet Angın Street, Nu:13, 17500, Çanakkale) \\ 2, Karamanoğlu Mehmet Bey University, Turkey (Yunus Emre Campus, 70200, Karaman) \\ * Correspondence to: Çanakkale Onsekiz Mart Üniversity, Gelibolu Piri Reis Vocational School, Yazıcızade District, Öğretmen \\ Refet Angın Street, Nu:13, 17500, Çanakkale/Turkey Email: polatyucekaya@comu.edu.tr
}

\begin{abstract}
The aim of this research is to examine the mediating role of organizational commitment in the relationship between strategic human resource management and individual performance. For this purpose, data were collected from SME businesses operating in Aksaray through convenience sampling method in the period covering February-March 2019. The questionnaire prepared to collect data consists of four parts. The first part of the questionnaire includes questions about the demographic characteristics of the survey participants. The second part of the questionnaire is about the strategic human resources management scale. In the second part of the questionnaire, a scale consisting of 9 statements, which was developed by Huselid (1995) and rearranged by Batram et al. (2007), was used. For the organizational commitment scale in the third part of the questionnaire, the scale consisting of 7 statements developed by Katsikea et al. (2011) was used. For the individual performance scale in the last part of the questionnaire, a scale consisting of 6 statements developed by Green et al. (2006) was used. The collected data were analyzed with the help of SPSS and SmartPLS statistics program, and the data were analyzed by frequency, reliability analysis, confirmatory factor analysis and structural equation modeling. According to the results of this study, it was determined that organizational commitment has a full mediating role in the relationship between strategic human resources management and individual performance. As strategic human resources management increases the organizational commitment of the employees, it has been concluded that it also positively affects their individual performance.
\end{abstract}

Keywords:

Strategic human resources management, Individual performance, Organizational commitment, Mediation effect Article Received: 18 October 2020, Revised: 3 November 2020, Accepted: 24 December 2020

\section{Introduction}

In the information age we are in, it is seen that the key factor in the survival of enterprises and providing sustainable competitive advantage is human resources when we consider the point where globalization has reached and the speed of development of technology. The strategic importance of individuals with different expectations, sources of motivation and needs for businesses has never been at such a key point. Businesses have started to approach human resources with a strategic thinking method in this way they work to achieve their goals and objectives. Traditional human resources management approaches that support the business in matters such as recruitment, training, development, personal affairs, and wages started to be insufficient towards the end of the 1970s, and strategic human resources management that will ensure optimum use of human resources has emerged. Strategic human resources management has undertaken important tasks in increasing the performance of enterprises and providing competitive advantage by raising people who are open to innovations, have high motivation, and will enable them to reflect their knowledge, skills, creative intelligence and abilities with a participatory understanding. The most obvious difference between strategic human resources management and traditional human resources management is performance criteria.

In this context, the aim of the study is to examine the mediating role of organizational commitment in the relationship between Strategic Human Resource Management and individual performance. The work consists of three parts. In 
the conceptual framework of the first part of the study, Strategic Human Resource Management, individual performance and organizational commitment were examined. In the second part of the study, the results of the survey and analysis were included to reveal the role of organizational commitment as a mediator in the relationship between Strategic Human Resource Management and individual performance. In the last part of the study, the results achieved were evaluated.

\section{Literature Review}

\subsection{Strategic Human Resources Management}

The perspective of the concept of human, which is the basic point of management science, has evolved over time and has come to the stage of accepting human as a resource. The "personnel management" approach constitutes the management models of the personnel working in public institutions and private enterprises in the 1950s. By the 1970s, the human resource perspective has been developed and human management actions have taken the form of "Human Resource Management" (Truss and Gratton, 1994). In the 1980s, a strategic perspective on Human Resource Management was developed and Human Resource Management began to be considered as "Strategic Human Resource Management" in the literature (Devanna et al., 1981). The basic idea of the transformation of human resources management into strategic human resources management lies in the necessity of addressing the human element that needs to be managed as a resource at a strategic level (Lengnick-Hall and Lengnick-Hall, 1988).

In strategic human resources management, two different approaches related to the human element are adopted. The first approach is to treat the human element as an output, and the second approach is to treat the human element as an input (Huselid et al., 1997). The goal of evaluating the human factor as output is the use of human as a strategic resource in order to maintain the ability of businesses to compete at a strategic level. The understanding of utilizing human resources in determining strategies at strategic level in order not to lose the competitive power of companies underlies the situation of accepting the human factor as input. Armstrong (2008) explains strategic human resources management as aligning and implementing human resources strategies with business strategies in the long term.

Baker (1999) explains that successful strategic human resource management practices will provide benefits in terms of reducing absenteeism, increasing business performance, improving problem-solving skills, decreasing workforce turnover, reducing costs, and reducing resistance to change. Schuler (1992) proposed the 5P model in order to achieve successful results from strategic human resource management practices. With the 5P model, it is recommended that companies turn to human resources policies, human resources psychology, human resources programs, human resources practices and human resources processes, and to develop solutions in this direction. Barutçugil (2004) emphasized the need for companies to act in strategic human resources practices with a future-oriented, marketoriented, talent-oriented and diverse focus. Market-oriented approach is to prefer human resources that can determine the changing demands and needs of the customers and establish close ties with the customers in the selection of human resources. Future-oriented approach is the orientation of companies to human resources in accordance with the company mission and vision. The talent-focused approach explains the preference of competent individuals who are capable of fulfilling the workload of companies. In the management of diversity, human resources suitable for managing individuals from different cultural backgrounds are created.

\subsection{Individual Performance}

Businesses have to use production factors to meet people's needs and expectations. The factors of production are classified as natural resources; labor, capital, entrepreneurs and technology. The most valuable resource that every organization needs in the production process is human resources (Garih, 2004). Meeting the qualified 
manpower required by the organization is extremely important for production activities. This situation raises the need to determine the talents of human resources and their contribution to the organization. For this reason, the concept of performance has an important place for organizations.

Performance is expressed as a concept that affects the results of activities carried out in order to reach pre-planned goals and is explained in absolute or relative ways in accordance with the determined criteria (Akal, 1996). Performance measurement studies are related to human activities, which are the most basic resource of the organization. In every organization, it is aimed to get the highest efficiency from human resources and performances are evaluated accordingly. Individual performance refers to the fact that the outputs of the employees as a result of their efforts in line with the goals of the organization are in harmony with the goals of the organization (Katerberg and Blau, 1983). Individual performance may vary depending on the employees' abilities, education levels, motivations, personal goals, and personalities. (Marchant, 1999). Therefore, it is possible to increase the individual performance of employees.

\subsection{Organizational Commitment}

The transformation of human resources approaches to strategic human resources approaches in the literature and application areas has led to the treatment of human resources at a strategic level. The strategic level has led to the effective and efficient use of human resources, the concentration of enterprises and academics on the relationship between the individual and the organization, and the work in this field. At this point, the level of commitment of individuals to businesses has an important place in order to maximize the benefits that businesses gain from their employees and to manage their human resources at a strategic level (Shore and Martin, 1989: 633). The concept of organizational commitment is discussed in the literature as giving up the benefits that individuals have for the business (Becker, 1960), individuals' acceptance of the norms and values of businesses (Sheldon, 1971) and individuals to form alliances by adapting to their organizational identities (Northcraft and Neale, 1990). In order to talk about the concept of organizational commitment in businesses, the primary requirement is that individuals are willing to adopt the mission, vision, purpose and values determined by the organization (Morrow, 1983). Porter et al. (1974) explains the preconditions of the concept of organizational commitment as believing in the goals determined by the organization and accepting the goals determined by the organization, the individual's willingness to strive for the organization, and the individual's desire to take part in the organization continuously. The process of employee commitment to organizations is based psychologically (Allen and Meyer, 1991). In order for individuals to develop a sense of commitment to organizations, norms, which are indicators of necessity, and requests, which are indicators of volunteering, must be accepted and internalized simultaneously (Meyer and Herscovitch, 2001: 317). In order to talk about the commitment of individuals to the organization, it is expected that the outputs of high employee performance and productivity, sense of belonging, low employee turnover and low job absenteeism are expected to be observed as a result of this commitment (Dawley et al., 2005).

In the literature, there are studies that try to explain the concept of organizational commitment by treating it differently according to the types of commitment. Kanter (1968: 499-517) suggests that three basic allegiances can be mentioned within organizational commitment, indicating that individuals are connected to organizations. These are the continuity commitment that ensures the permanent stay of the individual in the organization, the interlocking commitment that regulates the sense of belonging to the organization with social relations, and the control commitment that enables individuals to act in accordance with the organizational norms and values. O'Reilly and Chatman (1986) explain the 
types of commitment that enable individuals to reach the level of psychological competence that constitute their organizational commitment as compliance commitment in which reward and punishment sanctions play an active role, commitment to identification based on intraorganizational relations, and internalization commitment, which shows the full acceptance of organizational values by individuals. In the organizational commitment model introduced into the literature by Etzioni (1961), the types of commitment are explained as moral commitment that enables employees to identify with the norms, values and goals of the organization, calculative commitment based on intra-organizational relations and alienating commitment that enables the individual to move away from the organization. Penley and Gould (1988), on the other hand, discuss the types of commitment put forward by Etzioni and present the types of commitment of organizational commitment as moral commitment, self-seeking commitment and alienating commitment (Zangaro, 2001). Allen and Meyer (1990) classify the sub-commitment dimensions that enable the formation of organizational commitment as affective commitment that enables individuals to feel emotionally belonging to the organization, the continuance commitment that the individual creates to make the gains from the organization continuous, and the normative commitment that individuals feel obliged to take part in the organization (Meyer and Allen, 1991).

Wiener (1982) suggests that individuals should switch from instrumental commitment states based on their own interests to normative commitment states where organizational interests are prioritized in order to achieve organizational commitment. Becker (1960) explains that although individuals are not emotionally attached to the organization, they will act behaviorally in order to gain various benefits and that organizational commitment will occur in the behavioral dimension. Salancik (1977), on the other hand, argues that in order for behavioral commitment to be realized, both the organization and the individuals should intend to maintain this behavioral relationship pattern, but organizational commitment can occur as long as this mutual intention continues. Mowday et al. (1982), on the other hand, emphasizes the necessity of establishing an attitudinal commitment that implies that individuals adopt organizational goals in order to realize behavioral commitment based on the relationship between individual and organizational attitudes and behaviors.

Organizations are expected to build structures that strengthen organizational commitment within the organizational culture in order to use human resources effectively (Yumuşak, Özafşarlıoğlu, and Y1ld1z, 2013) and to maintain these structures with proactive and reactive attitudes. These attitudes contribute to the formation of organizational commitment by directly playing an active role on the degree of organizational commitment. Manetje (2009) discusses organizational commitment levels at three levels as low, medium and high. Low level of organizational commitment means that individuals maintain their level of commitment to the organization until they are met with a better option. Cognitive attitudes towards staying in individuals are formed by providing attitudinal commitment with moderate organizational commitment. With the high level of organizational commitment, individuals' intention to stay in the organization is increased to the level of behavioral commitment.

\section{Methods}

\subsection{Purpose, Scope And Limitations}

The aim of this research is to examine the mediating role of organizational commitment in the relationship between strategic human resource management and individual performance. For this purpose, data were collected from SME businesses operating in Aksaray by convenience sampling in the period covering February-March 2019. The questionnaire prepared to collect data consists of four parts, and the first part includes questions about the demographic characteristics of the survey participants. The second part of the 
questionnaire is about the strategic human resources management scale. In this section, a scale consisting of 9 statements developed by Huselid (1995) and rearranged by Batram et al (2007) was used. For the organizational commitment scale in the third part of the questionnaire, the scale consisting of 7 statements and developed by Katsikea et al. (2011) was used. For the individual performance scale in the last part of the questionnaire, the scale developed by Green et al. (2006) and consisting of 6 statements was used. The scales in the research are arranged according to the 5-point Likert scale as follows: "1 strongly disagree; 2 disagree; 3 neutral; 4 agree; 5 strongly agree". This research is limited to SME employees operating in Aksaray and scales prepared for the variables to be measured. Other constraints of the study are time and cost constraints. In the study, it was assumed that the sample represented the main population sufficiently, that the scales were sufficient to measure the variables and that the participants answered the statements in the questionnaire honestly and sincerely. The Smart PLS method was used in this study, and the studies of Kaya et al. (2020) were based on the tabulation of the research findings.

\subsection{Relationships between Variables}

In the study of Çankır (2019) examining the relationship between the job performance of public personnel and organizational commitment, it was determined that a one-unit increase in organizational commitment causes an increase of 0.63 units in workplace performance and that employee performance is largely dependent on the level of organizational commitment. Özdemir and Yaylalı (2014) found that there is a positive and high relationship between organizational commitment and performance in their study, in which they examined the relationships between organizational commitment, performance, and the intention to quit. In the study in which Uygur A (2007) investigated the relationship between organizational commitment and performance levels of employees in the banking sector, it was found that there was a moderate relationship.
In the research conducted by Erkoç (2009), it was determined that there is a positive relationship between strategic human resources management practices and employee performance. Huselid, Jackson, and Schuler (1997) concluded that there is a positive relationship between performance and strategic human resources management, according to the results of their study, which investigated the effect of strategic human resources management on company performance. Karakaya and Bayraktar found in their study that human resources practices have no effect on individual performance. Kılıçarslan and Marşap (2018) found in their study that there is a positive and strong relationship between strategic human resources management and organizational commitment. In the research conducted by Sultanli (2020) in Azerbaijan, it was determined that there is a moderate relationship between strategic human resources management and organizational commitment.

\section{Model and Hypotheses}

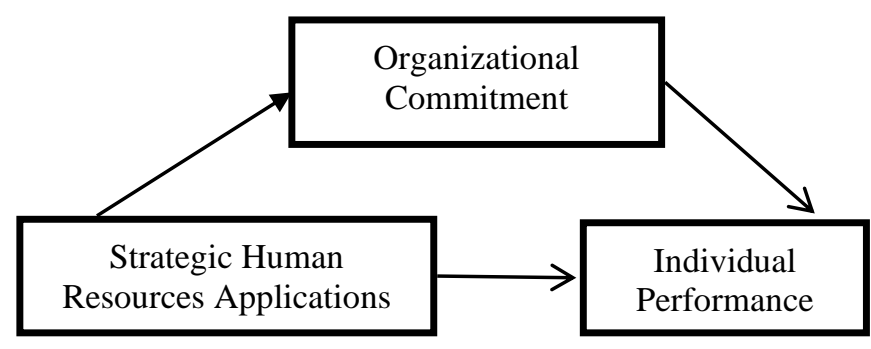

Figure 1: Research Model

The following hypotheses have been established based on the research model and literature:

H1: Strategic human resources management affects organizational commitment

H2: Organizational commitment positively affects individual performance

H3: Strategic human resources management positively affects individual performance

H4: Organizational commitment has a mediating role in the relationship between strategic human resources management and individual performance. 


\section{Data Analysis}

\section{Demographic Findings}

Information on the demographic characteristics of the participants is shown in Table 1.

Table 1. Demographic characteristics of the participants

\begin{tabular}{cccccc}
\hline Gender & $\mathbf{N}$ & $\mathbf{\%}$ & Educatio & $\mathbf{N}$ & $\mathbf{\%}$ \\
Female & 37 & 37,8 & Primary & 8 & 8,2 \\
Male & 61 & 62,2 & Secondary & 26 & 26,5 \\
Total & 98 & 100 & University & 42 & 42,9 \\
\cline { 1 - 3 } Marital & $\mathbf{N}$ & $\mathbf{\%}$ & Master $/$ & 21 & 21,4 \\
Married & 58 & 59,2 & Total & 98 & 1,0 \\
Single & 40 & 40,8 & & & \\
\hline Age & $\mathbf{N}$ & $\mathbf{\%}$ & Monthly & $\mathbf{N}$ & $\mathbf{\%}$ \\
$18-25$ & 18 & 18,4 & $2200-$ & 54 & 55,1 \\
$26-33$ & 41 & 41,8 & $3001-$ & 18 & 18,4 \\
$34-41$ & 28 & 28,6 & $4001-$ & 9 & 9,2 \\
$42-49$ & 9 & 9,2 & $5001-$ & 13 & 13,3 \\
$50+$ & 2 & 2,0 & 6001 and & 4 & 4,1 \\
Total & 98 & 100 & Total & 98 & 100 \\
\hline
\end{tabular}

When the demographic characteristics of the participants are examined, $62.2 \%$ are male participants and $37.8 \%$ are female participants. According to the marital status of the participants, $59.2 \%$ are married and $40.8 \%$ are single. According to their education levels, $64.3 \%$ of the participants are people with higher education. $26.5 \%$ of the participants are secondary education graduates and $8.2 \%$ of the participants are primary education graduates. When the age of the participants is examined, it is seen that $88.8 \%$ of the participants are 41 years and younger and $11.2 \%$ of the participants are 42 and above. When the monthly income of the participants is examined, it is seen that $55.1 \%$ of them earn an income between $2200-3000 \mathrm{TL}$, and $4.1 \%$ of the participants have an income of $6000 \mathrm{TL}$ or more. Other participants earn 3001-6000 TL.

3.2. Measurement Model (Confirmatory Factor Analysis) Results
It is observed that the use of covariance-based structural equation modeling (CB-SEM) was more preferred in many of the articles published until recently, but the use of PLS-SEM in articles in social sciences increased after 2010 (Hair et al. 2011: 139; Y1ld1z and Develi, 2019).

The necessity of analyzing the data with the bootstrapping method due to the relatively small amount of data obtained despite the large population has led to the use of variance-based PLS-SEM programs instead of programs such as covariance-based AMOS and Lisrel. For structure validity and reliability, analyzes were made taking into account indicators such as t-statistics, composite reliability (CR) and Average Variance Extracted (AVE). Hair et al (2017) recommend using the CR (composite reliability) coefficient instead of Cronbach alpha $(\alpha)$. "Outer Loading" factor loads and "Average Variance Extracted (AVE)" coefficients were taken into account for convergence validity (Kaya et al., 2020). "Fornell and Larcker Criterion" was taken into consideration for the discrimination validity. According to Fornell and Larcker (1981), the square root of the AVE coefficients should be greater than the correlation coefficients between other structures in the study. The results regarding reliability and validity in the study are shown in the table below. AVE value must be greater than or equal to 0.50 and less than 5 (Chin, 1998).

Table 2: Reliability, association and dissociation

\begin{tabular}{lllllll}
\hline Variables & ALFA & CR & AVE & 1 & 2 & 3 \\
\hline F-L & & & & & & \\
\hline STRIKKY &, 86 &, 90 &, 65 &, 80 & & \\
\hline ÖB &, 92 &, 94 &, 61 &, 64 &, 78 & \\
\hline BP &, 90 &, 92 &, 61 &, 73 &, 70 &, 78
\end{tabular}

The results of the measurement model analysis for reliability and validity of merger and dissociation are given in Table 2. When Table 2 is examined, it is seen that the CR values are 90-, 94-, 92, respectively, and the AVE coefficients are higher than 0.05. According to Hair et al (2019) in the examination of the indicator loads, it is suggested that the external indicator load of a reflective type 
structure should take a value of 0.708 and above in order to explain more than 50 percent of the variance in the models based on partial least squares. Hair et al (2017) states that external indicator loads should be higher than 0.70 in order to ensure indicator reliability. At the same time, Hair et al (2017) states that the indicators in the range of $0.40-0.70$ should be excluded from the model and observed whether there is an improvement in the combined reliability and explained average variance (AVE) coefficients, and if there is no improvement, the indicators should be preserved. According to FornellLarcker criteria, the square root of the explained mean variance (AVE) value of a variable must be greater than the correlation coefficient (AVE> r) with other variables (Fornell and Larcker, 1981; Y1ldız and Develi, 2019). It is seen that this condition is also met according to what is given in Table 2.

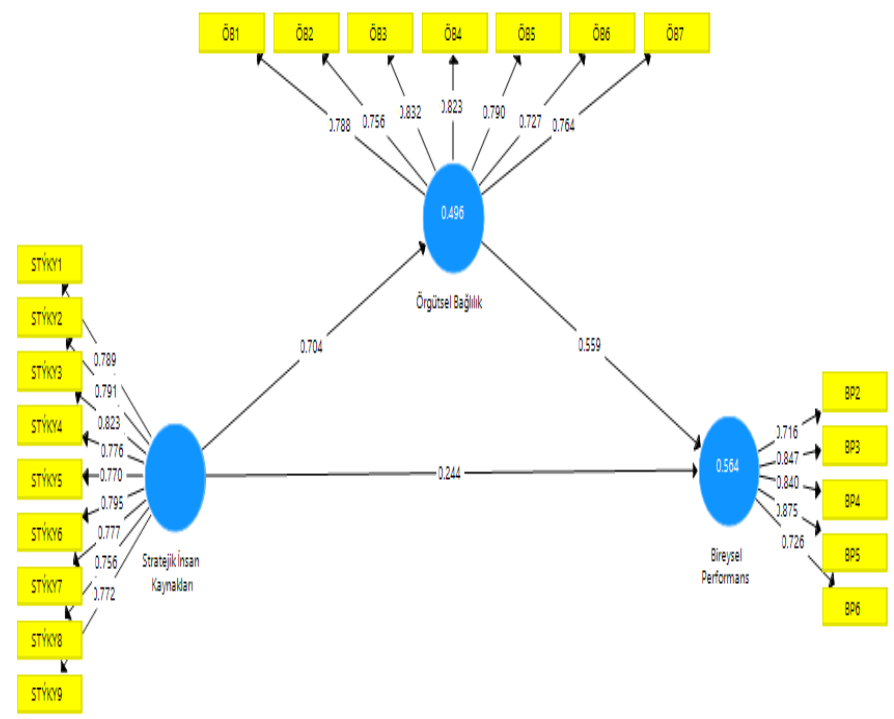

Figure 2: Measurement model results

Note: The values between the indicators and the latent variable are factor loadings. Values between latent variables are standardized Beta coefficients. Figure 2 shows the factor loadings and standardized Beta coefficients for the variables. Factor loadings are expected to be >,708 and factor loadings for factors are expected to be $\mathrm{p}$ $<.05$ (Hair et al, 2013). The variables used in the study fulfill this condition.

\subsection{Results of Structural Model}

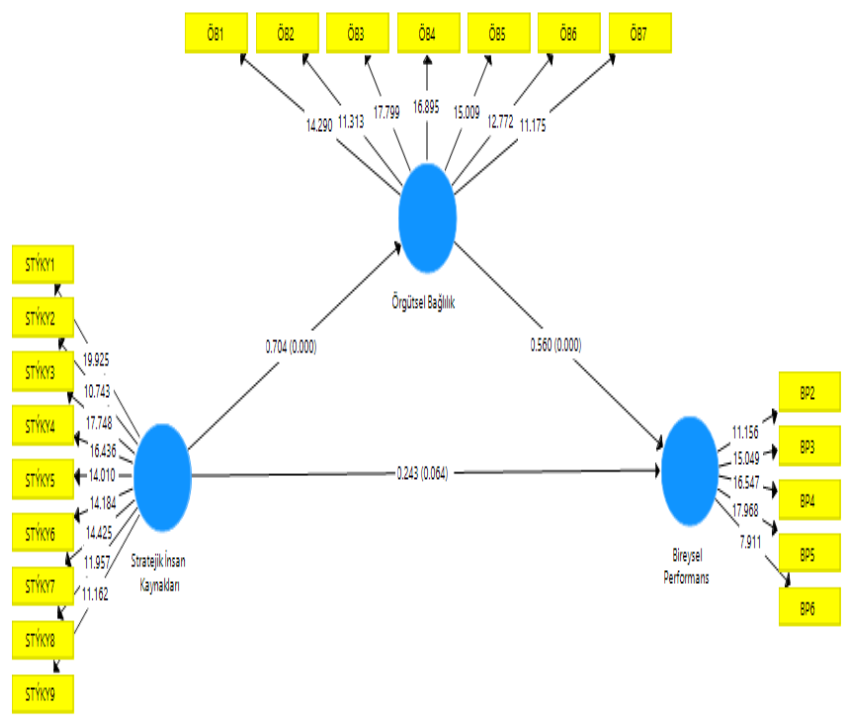

Figure 3: Results of Structural Equation Model

Note: Values between indicators and latent variables are $\mathrm{t}$ values. The variables between latent variables are standardized Beta coefficients. The values in parentheses are $p$ (significance) value.

Since the results obtained from the measurement model analysis were sufficient, structural model analysis was applied to the variables. In the structural model analysis, the derivative sampling (bootstrapping) method was used. In the derivative sampling method, the 5000 derivative sample number recommended by Hair et al (2017) and Henseler et al (2016) was preferred. The structural model is shown in Figure 3.

According to the measurement model in Figure 2 and the data shown in the structural equation model in Figure 3, strategic human resources management has a positive effect on organizational commitment $(\beta=0,704, \rho=$ $0,000)$. Organizational commitment variable also has a positive effect on individual performance $(\beta$ $=0,560, \rho=0,000)$. Therefore, the $\mathrm{H} 1$ and $\mathrm{H} 2$ hypotheses were supported. Strategic human resources management does not have a positive effect on individual performance $(\beta=0,243$, $\rho=0,064)$. Since $\rho>0.05$, the H3 hypothesis was not supported. However, according to the results of the analysis, strategic human resources management has a significant effect on individual performance $(\beta=0,394, \rho=0,001)$. The data set collected by the Bootstrapping analysis method 
was analyzed by simulating 5000 samples, and it was determined that organizational commitment had a full mediating role in the relationship between strategic human resources management and individual performance $(\mathrm{Bias}=0,020 ; 2,5 \%=$ $0,203 ; 97,5 \%=0,664) . \quad \mathrm{H} 4$ hypothesis is supported (Zhao et al., 2010; Kaya et al., 2020).

Conclusion

Strategic human resources management is the human resources activities that organizations implement in a planned way in order to achieve their targeted results. The main subject of human resources activities is the human factor. Organizations that want to survive in competitive conditions must evaluate the human factor as a strategic resource. It is desirable that the performance of the employees in the organization is at the highest level. High-performing employees make valuable contributions to the organization's mission and vision, while also playing a key role in achieving sustainable profits. As a result of performance evaluation from human resources practices, extremely important results are obtained in terms of employees such as promotions, awards and penalties. High employee performance is a desired goal for every organization. By ensuring and increasing the organizational commitment of human resources, an important step has been taken in achieving the success and goals of the organization and achieving high employee performance.

The results of this study show that strategic human resources management affects organizational commitment. This result shows that strategic human resources management has an important contribution to the employees' sense of commitment to the organization. In addition, organizational commitment affects employee performance. Employees' feeling connected to the organization will reflect positively on their performance and it will be easier for the organization to reach its goals. The increase in employee performance means a great value for the organization. In every organization, managers make an effort to maximize the performance of employees. This goal, which is tried to be reached by gaining a sense of commitment, can be achieved. Strategic Human Resources Management also has a positive impact on employee performance. Employees ' performance is not affected by a single variable. There can be hundreds of different variables that affect performance. Of the variables discussed in this study, Strategic Human Resource Management is also one of the variables that has an impact on performance. Another of the results obtained in the study is that organizational commitment has a full mediating effect on the impact of Strategic Human Resource Management on employee performance. In other words, the impact of Strategic Human Resources Management on employee performance can only be realized through ensuring organizational commitment.

Our recommendation for the next researchers is to investigate other variables that are or may affect employee performance, which is extremely important for organizations. Also, it is also suggested to add some moderator (e.g., personality traits and organizational culture) and mediator variables (e.g., job satisfaction and motivation) and negative outcome variables (such as counter-productive workplace behaviors) to the research model (Yildiz, 2019). It is important to determine whether the study gives similar results for white-collar workers because the career plan for them is determined more clearly.

\section{References}

[1] Akal, Z. (1996) Işsletmelerde Performans Ölçüm ve Denetimi, Ankara: MPM Yayınları, No: 473.

[2] Allen, N. J., Meyer, J. P. (1990) The Measurement and Antecedents of Affective, Continuance and Normative Commitment to the Organization, Journal of Occupational Psychology, 63, 1-18.

[3] Allen, N. J., \& Meyer, J. P. (1993). Organizational Commitment: Evidence Of Career Stage Effects?. Journal of Business Research, 26(1), 49-61. 
[4] Amstrong, M. (2008). Strategic Human Resource Management: A Guide to Action. London, GBR: Kogan Page Ltd.

[5] Devanna, M. A., Fombrun, C., \& Tichy, N. (1981). Human Resources Management: A Strategic Perspective. Organizational Dynamics, 9(3), 51-67.

[6] Baron, R M. \& Kenny, D A. (1986) The Moderator-Mediator Variable Distinction İn Social Psychology Research: Conceptual, Strategic And Statistical Considerations. Journal Of Personality And Social Psychology 51(6), 1173-1182.

[7] Bartram, T., Stanton, P., Leggat, S., Casimir, G. and Fraser, B. (2007) Lost İn Translation: Exploring The Link Between HRM and Performance İn Healthcare. Human Resource Management Journal, 17(1), 21-41.

[8] Barutçugil, İ. (2004) Stratejik Insan Kaynakları Yönetimi. İstanbul: Kariyer Yayınları.

[9] Becker, H.S., (1960) Notes on The Concept of Commitment, The American Journal of Sociology, Vol.66, Issue:1.

[10] Çankır B. (2019) Örgütlerde Duygusal Bağlılık ve Performans İlişkisi, İstanbul Gelişim Üniversitesi Sosyal Bilimler Dergisi 6:155-177.

[11]David, B. (1999) Strategic Human Resource Management: Performance, Alignment, Management. Librarian Career Development, 7(5), 51-63.

[12] Dawley, D. D., Stephens, R. D., and Stephens, D. B. (2005) Dimensionality of Organizational Commitment in Volunteer Workers. Journal.of Together we will beat cancer.

[13]Erkoç, D. (2009). Stratejik İnsan Kaynakları Yönetimi Uygulamaları İle İşletme Performans Değerlendirme Sistemi Arasındaki İlişki Üzerine Bir Araştırma, Yayınlanmamış Yüksek lisans tezi, Marmara Üniversitesi, Sbe, İstanbul.

[14]Etzioni, A. (1961). A comparative analysis of complex organizations. Glen- coe, Ny. Free Press.
[15]Fornell, C., Larcker, D. F.(1981) Evaluating Structural Equation Models With Unobservable Variables And Measurement Error Journal Of Marketing Research, 18(1), 39-50.

[16]Garih, Ü. (2004), Yönetim Teknikleri, 1. Baskı, İstanbul: Hayat Yayıncılık.

[17] Green, K.W., C. Wu, D. Whitten, B. Medlin (2006) The Impact of Strategic Human Resource Management on Firm Performance and HR Professionals' Work Attitude and Work Performance, The International Journal of Human Resource Management, 17(4), 559579

[18] Hair, J. F., Black , W. C., Babin B. J., Anderson R.e. \& Tatham R. L. (2010). Multivariate Data Analysis (7th Ed.) NJ:Pearson Prentice Hall

[19] Hair, J. F., Hult, G. T. M., Ringle, C.M.\& Sarstedt, M. (2017) A Primer on Partial Least Squares Structural Equation Modeling (PLSSEM), ( $2^{\text {nd }}$ Ed. $), \quad$ Los Angeles, Sage Publications.

[20] Hair, J. F., Risher J., J., Sarstedt, M. \& Ringle C., M. (2019) When to use and how to report the results of PLS-SEM, European Business Review, 31(1). 2-24.

[21] Henseler, J., Hubona G \& Ray P. A. (2016) Using Pls Path Modeling In New Technology Research: Updated Guidelines, Industrial Management \& Data Systems, Vol.116, No.1, ss.2-20.

[22] Huselid, M. A. (1995). The İmpact of Human Resource Management Practices on Turnover, Productivity, And Corporate Financial Performance. Academy of Management Journal, 38(3), 635-672.

[23] Huselid, M. A., Jackson, S. E., \& Schuler, R. S. (1997). Technical and Strategic Human Resources Management Effectiveness as Determinants of Firm Performance. Academy of Management Journal, 40(1), 171-188.

[24] Kanter, R. M., (1968). Commitment and Social Organization: A Study of Commitment Mechanisms in Utopian Communitise. 
American Sociological Review, C.33, S. 4, 499-517.

[25] Karakaya K. \& Bayraktar O.(2020) İnsan Kaynakları Uygulamalarının Bireysel Performansa Etkisi Ekonomi, Işsletme ve Maliye Araştırmaları Dergisi, Cilt 2, Sayı 2, s.170-184

[26] Katerberg, R., Blau, G. (1983) An Examination of Level and Direction of Effort and Job Performance, Academy of Management Journal, 26(2), 249-257

[27] Katsikea, E., Theodosiou, M., Perdikis, N. ve Kehagias, J. (2011) The Effects of Organizational Structure and Job Characteristics On Export Sales Managers' Job Satisfaction and Organizational Commitment, Journal of World Business, Say1: 46, s.221-233.

[28] Kaya B., Abubakar, A. M., Behravesh, E., Yildiz, H., \& Mert, İ.S. (2020) Antecedents of Innovative Performance: Findings from PLSSEM and Fuzzy Sets (fsQCA). Journal of Business Research, 114, 278-289.

[29] K1lıçaslan Ö, Marşap A. (2018) Stratejik İnsan Kaynakları Yönetimi Ve Örgütsel Bağl1lığa Etkisi, International Journal of Labour Life and Social Policy, 1 (2), 5-23.

[30] Lengnick-Hall, C. A., \& Lengnick-Hall, M. L. (1988) Strategic Human Resources Management: A Review of the Literature and A Proposed Typology. Academy of management Review, 13(3), 454-470.

[31]Manetje, O.M., (2009) The Impact of Organisational Culture On Organisational Commitment, Thesis University of South Africa.

[32] Marchant, T. (1999) Strategies for Improving Individual Performance and Job Satisfaction At Meadowvale Health, Journal of Management Practice, 2 (3), 63-70.

[33] Meyer, J. P., Allen, N. J. (1991) A ThreeComponent Conceptualization of Organizational Commitment. Human Relations, 1, 61-89.

[34] Meyer, J. P., Allen, N. J., \& Smith, C. A. (1993) Commitment to Organizations and
Occupations: Extension and Test of a ThreeComponent Conceptualization. Journal of Applied Psychology, 78 (4), pp.538.

[35] Meyer, J. P. and Herscovitch, L. (2001) Commitment in the Workplace Toward a General Model. Human Resource Management Review, 11, 299-326.

[36] Miles. E.W., Patrick, S., \& King, W.C., (1996) Job Level as A Systemic Variable in Predicting the Relationship Between Supervisory Communication and Satisfaction. Journal of Occupational and Organizational Psychology, 69, pp.277-292.

[37] Morrow, P. C. (1983) Concept Redundancy in Organizational Research, the Case of Work Commitment. Journal of Occupational Behavior, 34, 40-56.

[38] Mowday, R. T., Porter, L. W. and Steers, R. M. (1982) Employee-Organization Linkages: The Psychology of Commitment, Absenteeism, and Turnover. New York: Academic Press

[39] Northcraft, G. B. and Neale, M. A. (1990) Organizational Behavior Management Challenge. USA: The Dryden Pres.

[40] O'Reilly, C.; Chatman, J. (1986). Organizational Commitment and Psychological Attachment: The Effects of Compliance, Identification and Internalization on Prosocial Behaviour, Journal of Applied Psychology, 71 (3), 492-499.

[41] Özdemir H. \& Yaylalı A. (2014) Çalışanın Örgütsel Bağlılığ1, Performans1 Ve İşten Ayrılma Niyeti Arasındaki İlişkinin Belirlenmesine Yönelik Bir Araştırma, Journal Of Recreation And Tourism Research (JRTR), 1 (1), 48-58.

[42] Penley, L.E. and Gould, S., (1988) Etzioni's Model of Organizational Involvement: A Perspective For Understanding Commitment to Organizations, Journal of Organizational Behavior, Vol.9.

[43] Porter, L.W., Strees, R.M., Mowday, R.T. and Boulian, P.V., (1974) Organizational Commitment, Job Satisfaction, and Turnover Among Psychiatric Technicians, Journal of Applied Psychology, Vol. 59. 
[44] Salancik, G.R. (1977). Commitment and The Control of Organizational Behavior And Belief. In B.M. Staw \& G.R. Salancik (Eds.), NM Directions İn Organizational Behavior (pp. 1-54), Chicago: St. Clair Press.

[45] Schuler, R. S. (1992) Strategic Human Resources Management: Linking The People with The Strategic Needs of the Business. Organizational Dynamics, 21(1), 18-32.

[46] Sheldon, M.E. (1971) Investments and Involvements as Mechanisms Producing Commitment to the Organization, Administrative Science Quarterly, 16(2), 143150.

[47] Shore, L. M. ve Martin, H. J. (1989). Job Satisfaction and Organizational Commitment in Relation to Work Performance and Turnover İntentions. Human Relations, Volume 42, Number 7, 625-638.

[48] Sultanli L. (2020) The Relationship Between Strategic Human Resource Management And The Organizational Commitment:The Case of Azerbaijan, 55th International Scientific Conference on Economic and Social Development, 18-19 June, Baku, 63-70.

[49] Truss, C., Gratton, L. (1994). Strategic Human Resource Management: A Conceptual Approach. International Journal of Human Resource Management, 5(3), 663-686.

[50] Uygur A. (2007) Örgütsel Bağl1lık İle İşgören Performansı İlişkisini İncelemeye Yönelik Bir Alan Araştırması Yönelik Bir Alan Araştırması, Ticaret ve Turizm Eğitim Fakültesi Dergisi, No: 1, s.71-85

[51]Wiener, Y., (1982), Commitment in Organizations: A Normative View, Academy of Management Review, Vol.7, Issue:3.

[52] Yıldı, H., \& Develi, A. (2019). Özel ve Kamu Sektöründeki Çalışanların Sendikalara Yönelik Güncel Bakış Açıları. 10. Uluslararası Sivil Toplum Kuruluşları Kongresi Bildiriler Kitabl, Bandırma Onyedi Eylül Üniversitesi, Balıkesir, ss.552-558.

[53] Yildiz, H. (2019). The Interactive Effect of Positive Psychological Capital and
Organizational Trust on Organizational Citizenship Behavior. SAGE Open, 9(3), 2158244019862661.

[54] Yumuşak, S., Özafşarlığlu, S., \& Yıldız, H. (2013). İş Tatmini İle Örgütsel Bağlilık Arasındaki İlişkinin İncelenmesi: Uşak Tekstil Sektöründe Bir Uygulama. Ege Stratejik Araştırmalar Dergisi, 4(2), 56-79.

[55]Zangaro, G.A. (2001) Organisational Commitment: A Concept Analysis. Nursing Forum, 36, 14-23.

[56]Zhao X., Lynch, J. G. \& Chen, Q. (2010) Reconsidering Baron and Kenny: Myths and Truths About Mediation Analysis, Journal of Consumer Research Inc., 37(2),197-206. 